\title{
Article
}

\section{Interrogating Conflicting Narratives of Writing in the Academy: A Call for Research}

Katie Bryant

McGill University

A safe haven in an often unsafe place: I would use this metaphor to describe the space writing studies and a university writing centre have offered me, as I've attempted to find my own place as a feminist in the academy. I feel these two things are my rocks. They are firm, solid places for me to reside amongst the challenges I've experienced as a writer. The reasons for my struggles with writing for academic purposes are difficult to pinpoint. Some would say they stem from my lack of literacy, hinting that laziness could be a culprit. Others might suggest they are connected to my subjective identity as a first-generation, female university student. Or others might take the discussion of subjective identity a bit further, arguing that my identity as a feminist, and my determination to bring my feminist politics into my academic work explain these challenges.

Reflecting on my situation, I sense my struggles are connected to something outside of and much larger than my own identity. Specifically, I sense they are connected to something David Russell (2002) makes visible in his history of writing and writing support in the academy. He explains that until the late nineteenth century, only a few, elite members of society were admitted to the university. In other words, it was only white, upper class men who were allowed to enter the academy, with the intention that their liberal arts educations would prepare them to assume positions "as full members of the nation's governing elite," becoming ministers, politicians, or lawyers (2002, p. 21). Of course many would argue that things have changed significantly in the academy since the late nineteenth century, pointing specifically to the dramatic increase in "non-traditional" student enrollment in universities across the globe (Bazerman, 2008). This is a point with which I would heartily agree, as these systematic, quantitative gains are extremely important in redressing social inequity in the academy and beyond. Yet, at the same time, I would also argue that the less visible, more systemic components of this highly traditional and elite system need further interrogation. For example, I 
Volume 27, 2017

http://journals.sfu.ca/cjsdw

wonder how the academy's elitist and exclusionary historical foundations might continue to inform occluded, tacit, systemic components of its current practices?

Obviously such a large question cannot be answered in this commentary. I raise it because I would like to explore how it might connect with two narratives of writing I have seen vying for position in academe. I would term these narratives the writing as social action narrative and the writing as skill narrative. In the following paragraphs, I describe these narratives of writing by drawing on the empirical work of others in the discipline of writing studies, as well as my own experiences working in this field. Following that, I briefly explore how we, as a community of writing scholars and practitioners can begin to further interrogate these opposing narratives of writing to gain appropriate legitimacy and recognition for the work we do in the academy.

For those of us situated in the field of writing studies, the writing as social action narrative is most likely common knowledge. It is a theoretically informed notion of writing that comes from decades of research done by scholars in our field. These scholars tend to interrogate how a particular group of people, in a particular setting, use written discourse to accomplish the social tasks of their contexts. Paré (2009) writes:

[...] by saying that writing is social action I mean at least two things: first, it is a specialized and collective practice that develops locally, in communities, in organizations, and disciplines, and that one learns to join or participate in. Second, [...] writing makes things happen, it has consequences [...] We don't write writing, we write something - a proposal, an argument, a description, a judgement, a directive - something that we hope will have an effect, will have results, change minds, spur to action, create solidarity, seed doubt. (p. 4)

In this view then, writing is a way to get things done in a particular context. It is an ongoing social process that is not learned once and for all. Instead, as has been well illustrated through numerous empirical studies in our field, individuals learn how to use the discourse conventions of their community as they move from novice to more experienced community members. Their movement occurs as they continue to use the community's genres to participate in its communicative activities. And their ability to use these genres, and hence move into more expert positions in their new communities is eased and aided through mentoring from a more experienced community member. 
Volume 27, 2017

http://journals.sfu.ca/cjsdw

In contrast to this conceptualization of writing that tends to inform our work in this field, we are also aware of another narrative lurking close by. This is the writing as skill narrative, in which writing is perceived as something that:

[...] can be mastered once and for all, preferably before students arrive at the university. Part of this attitude comes from underlying definitions of writing as spelling, grammar, and handwriting (transcription) and the consequent definition of writing instruction as remediation of deficiency. (Graves, 1994, p. 82)

This notion of writing does not appear to be informed by the empirical work of researchers in any field of study. Instead, its dominance seems to come from tools like "the complaint tradition of student writing" (see Giltrow, 2002; Lu, 1992; Milroy \& Milroy, 1991) or "the myth of transience" (see Rose, 1985).

In my own case, I was introduced to the writing as social action narrative after becoming a writing tutor at our university's writing centre near the end of my undergraduate studies. This opportunity allowed me to realize that an entire field of research exists that could potentially explain my own writing challenges in the university. Specifically, this discipline and the accompanying narrative of writing it offered helped me understand that it might not be my own innate lacks that explained the reasons for my struggles to write in this context. Instead, there were empirically informed explanations to make sense of my challenges, as well as help me understand how to overcome them. It became even more apparent how this field of study, its accompanying writing centre, and its narrative of writing could provide me a safe haven as I began my post-graduate work in writing studies, becoming more immersed in this discipline's research and theory.

Interestingly, though, as I continued to work in this field, eventually becoming the coordinator of a Canadian university's writing centre, I realized that my safe haven isn't always that safe. Rather, I began to see that it requires a great deal of effort on the part of writing studies practitioners to have our ideas and practices taken seriously, as our writing centres are often under siege by university administrators. This lack of legitimacy, and these constant sieges are why statements, like the recent "Statement on Writing Centres and Staffing" (Graves, 2016), which was composed by group of individuals working in the field of writing studies in Canada, are necessary. This statement is important because it offers a line of defence to protect our 
Volume 27, 2017

http://journals.sfu.ca/cjsdw

empirically informed ways of thinking about writing, and the ways they inform our methods of supporting students with this activity.

Yet, as I read the statement, I couldn't help feel that something was missing. As I reflected on it and thought about the sieges I myself experienced in my role as coordinator of a writing centre, I realized that my discomfort came from the fact that the statement overlooks key causes of our challenges. In other words, although many aspects of the statement are extremely important, I did not see where it explicitly expressed the need for those individuals outside of our discipline to begin to take up our empirically informed narrative of writing. And I would argue that uptake of this narrative of writing is extremely important, because, in my own experience, I feel it is the core reason for the challenges I face doing my writing practitioner work. Put differently, in my previous work as a writing centre tutor, coordinator, and instructor, my approach to supporting students with writing was informed by the writing as social action narrative. But I often found myself at odds with university administrators, faculty members, and students whose ways of thinking about writing were informed by the dominant writing as skill narrative. This resulted in them perceiving writing to be a skill and wanting quick fixes or editing support to address their own or their students' supposed "problems" with writing.

Similarly, studies of how writing is conceptualized and supported in the Canadian university context have illustrated that this writing as social action narrative does not inform how university senior administrators or faculty members think about writing. Rather, Graves (1994) found that most university administrators and faculty members conceptualize writing as a skill not a social action. This means their approach to writing support, if any, tends to focus on remediating student's writing deficiencies and helping them master particular skills once and for all, especially before they enter the workforce. Needless to say, it is university administrators' and faculty members' views of writing that then inform decisions about policies and practices of writing instruction, leading to many of the difficulties we encounter as writing specialists.

Thus, as writing studies researchers and practitioners, we need to work to challenge this mainstream narrative of writing that appears to pervade the university. To do this, rather than focusing on the concrete work of writing centres, I am echoing Parés (2017) call that we, as a community of researchers working in the fields of writing studies and rhetoric, need to continue Canadian universities' strong tradition of writing research. But, more specifically, I want to suggest that we as a research community engage in empirical work that can begin to interrupt this dominant narrative of writing that permeates so many corners of the university context - a 
Volume 27, 2017

http://journals.sfu.ca/cjsdw

narrative that makes it difficult for us to engage in our work in this context as writing scholars and practitioners.

Questions that can act as starting points to develop more concrete investigations into these issues are ones such as the following:

1. How did this writing as skill narrative come to pervade the university context?

2. What are the possible reasons for this narrative's dominance?

3. How can we begin dismantling the dominant position this non-empirically informed narrative of writing seems to have in this context?

4. How does this narrative's continued dominance devalue the work we, as writing scholars and practitioners do in the academy?

I am aware that designing research studies, and more specifically finding methodological approaches to uncover such occluded, systemic practices can be particularly difficult (see Paré, 2002). Yet I would suggest that these challenges can be addressed by continuing to align our work and forming collaborations with activist researchers in other disciplines (e.g., feminist theory and critical race theory). Such collaborations can prove fruitful, as researchers in these fields tend to focus specifically on making visible and challenging dominant narratives that can maintain social inequities in their own areas of research.

I will conclude by suggesting two important things that can be accomplished by engaging in this type of empirical work. First, we can illustrate to those outside our discipline why the concrete, day-to-day work of writing specialists in locations like our university writing centres are invaluable and indispensable (see Klostermann, this issue). Second, and returning to the metaphor that started this commentary, we will maintain the safe havens-the rocks-that writing studies and university writing centres can offer students. These sites of safety are especially important for students who may be struggling to use the discourses and genres of their disciplines to construct different ways of knowing-ways that might challenge the elitist and exclusionary foundations of the very structure in which they are now situated.

\section{Acknowledgments}

I would like to thank Janna Klostermann, Joel Heng Hartse, Roger Graves, Sibo Chen, and an anonymous reviewer for helpful feedback on earlier versions of this article. 
Volume 27, 2017

http://journals.sfu.ca/cjsdw

\section{References}

Bazerman, C. (2008). Introduction. In C. Bazerman (Ed.), Handbook on writing research: History, society, school, individual, text (pp. 1-4). New York, NY: Lawrence Erlbaum Associates.

Giltrow, J. (2002). Academic writing: Writing \& reading in the disciplines (3rd ed.). Peterborough, ON: Broadview Press.

Graves, R. (1994). Writing instruction in Canadian universities. Winnipeg, MB: Inkshed Publications.

Graves, R. (2016). Statement on writing centres and staffing. Canadian Journal for Studies in Discourse and Writing/Rédactologie, 26, 5-10.

Klostermann, J. (2017). Writing on the ground. Canadian Journal for Studies in Discourse and Writing/Rédactologie, 27, 19-23.

Lu, M. (1992). Conflict and struggle: The enemies or preconditions of basic writing? College English, 54(8), 887-913.

Milroy, J. \& Milroy, L. (1991 [1985]). Authority in language: Investigating language prescription and standardization. London/New York: Routledge.

Paré, A. (2017). The once and future writing centre: A reflection and critique. Canadian Association for Studies in Discourse and Writing/Rédactologie, 27, 1-8.

Paré, A. (2009). What we know about writing, and why it matters. Compendium ${ }_{2}$ : Writing, teaching, and learning in the university, 2(1), 1-7.

Paré, A. (2002). Genre and identity: Individuals, institutions, and ideology. In R. Coe, L. Lingard, \& T. Teslenko (Eds.), The rhetoric and ideology of genre (pp. 57-71). Cresskill, NJ: Hampton Press.

Rose, M. (1985). The language of exclusion: Writing instruction at the university. College English, 47(4), 341-359.

Russell, D. R. (2002). Writing in the academic disciplines: A curricular history, 1870-1990 (2nd ed.). Carbondale, IL: Southern Illinois University Press. 